\title{
Conventional and high-resolution heavy mineral analyses applied to flysch deposits: comparative provenance studies of the Ropianka (Upper Cretaceous-Paleocene) and Menilite (Oligocene) formations (Skole Nappe, Polish Carpathians)
}

\author{
Dorota SALATA ${ }^{1, *}$ and Alfred UCHMAN ${ }^{1}$ \\ 1 Institute of Geological Sciences, Jagiellonian University, Oleandry 2a, 30-063 Kraków, Poland
}

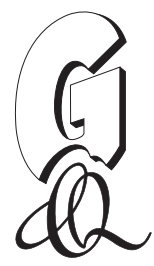

Salata D. and Uchman A. (2013) Conventional and high-resolution heavy mineral analyses applied to flysch deposits: comparative provenance studies of the Ropianka (Upper Cretaceous-Paleocene) and Menilite (Oligocene) formations (Skole Nappe, Polish Carpathians). Geological Quarterly, 57 (4): 649-664, doi: 10.7306/gq.1119

\begin{abstract}
Conventional and high-resolution analyses of heavy minerals from the gravity flow-deposited sandstones of the Campanian-Maastrichtian interval of the Ropianka (Upper Cretaceous-Paleocene) and Menilite (Oligocene) formations of the Polish Carpathians display similar compositions in terms of mineral species. Zircon, tourmaline, rutile, garnet, staurolite and kyanite belong to the main constituents in both formations. Apatite is common in the Ropianka Fm., while the Menilite $\mathrm{Fm}$. almost lacks this mineral. Furthermore, individual hornblende grains were found in the Ropianka Fm., while andalusite is present only in the Menilite Fm. The Ropianka Fm. is relatively richer in zircon, tourmaline, garnet and apatite, while the Menilite Fm. contains more staurolite and kyanite. Zircon and tourmaline colour and morphological varieties are similar in both formations. The similarities of the heavy mineral assemblages studied suggest origin of these minerals from lithologically similar rocks. Negative correlations between the zircon + tourmaline + rutile (ZTR) values and the content of garnet and staurolite in the Ropianka Fm. may indicate, to a large extent, first-cycle delivery of garnet and staurolite to the formation. Negative, but low, correlation valid only for ZTR and garnet and positive correlations for ZTR and staurolite and kyanite in the Menilite $\mathrm{Fm}$. suggest delivery of these minerals from sedimentary rocks or/and palimpsest sediments. The data obtained on mineral relationships and their morphology suggest mixed first-cycle and recycled provenance of the heavy minerals studied. Additionally, the first-cycle material input seems to be larger during the Ropianka Fm. sedimentation, while during the deposition of Menilite Fm. the contribution of material delivered from erosion of recycled sediments appears more prominent. The heavy mineral evidence suggests a change at the northern margin of the Skole Basin from an immature passive margin with a high relief during sedimentation of the Campanian-Maastrichtian part of the Ropianka Fm. to a mature passive margin with a low relief during sedimentation of the Menilite Fm.
\end{abstract}

Key words: heavy minerals, high-resolution, sedimentary provenance, flysch, Outer Carpathians, Skole Nappe.

\section{INTRODUCTION}

Lithological reconstructions of source areas and provenance studies of clastic deposits are a field of interest for researchers dealing with non-existing source massifs. Exotic rock studies, composition of sandstones and heavy mineral analyses are usually used as tools in such research.

Lithologically diverse suites of exotic rock pebbles are relatively frequent in strata of the Ropianka Formation and in some types of younger deposits such as Babica Clay (e.g., Wdowiarz, 1949; Bukowy, 1957; Kotlarczyk and Śliwowa, 1963; Bromowicz, 1974, 1986; Skulich, 1986; Rajchel, 1990; Rajchel and Myszkowska, 1998). By contrast, deposits of the Menilite For-

\section{* Corresponding author, e-mail: dorota.salata@uj.edu.pl}

Received: May 22, 2013; accepted: July 12, 2013; first published online: September 19, 2013 mation are poor in exotic pebbles (e.g., Kotlarczyk and Śliwowa, 1963; Ślączka and Unrug, 1966; Kotlarczyk, 1976). In such cases palaeogeographic studies and lithological reconstruction of source area based on exotic rocks is possible only for a narrow time-span, hindering comparative studies. The sandy fraction is abundant throughout the succession representing the entire Late Cretaceous-Oligocene time-span in the Skole Ba$\sin$. However, the composition of flysch sandstones is very monotonous (e.g., Kamieński et al., 1967; Bromowicz, 1974) and generally very similar in many facies. By contrast, heavy minerals provide much information. Therefore, heavy mineral analysis is an excellent tool for comparative studies and provenance interpretation. The choice of the Ropianka and Menilite formations allows comparison of initial and late stages of the history of the source area supplying western parts of the northern margin of the Skole Basin.

Previous heavy mineral studies of Upper Cretaceous and Oligocene strata of the Skole Basin were concentrated in the eastern and most southeastern part of the Skole Nappe (e.g., Jaskólski, 1931; Tokarski, 1947; Szczurowska, 1970, 1971, 1973; Wdowiarz et al., 1974; Żytko, 1975). Analyses were 
made mostly in rocks drilled in deep boreholes. In the area currently researched, heavy mineral assemblages have been briefly described only in the Węgierka Marl (Geroch et al., 1979) in the upper part of the Ropianka Formation (Kotlarczyk, 1978). These studies were limited to basic optical descriptions of heavy minerals and provided basic information about mineral content or only on the relative proportions of minerals. Palaeogeographic interpretations or lithological reconstructions of source massif(s) were usually not made or treated only briefly, while comparative study of heavy minerals from the Ropianka and Menilite formations was not conducted.

Heavy mineral analysis is a useful tool in identification of sediment provenance. However, due to commonly known factors influencing heavy mineral assemblages, such as transportation processes, including hydraulic selection, diagenetic changes and mixing of source material (e.g., Morton and Hallsworth, 1999; Mange and Wright, 2007a), heavy mineral data are difficult to interpret. This is especially true for multi-cycle or mixed-source sedimentary rocks to which flysch strata often belong.

The most commonly used method in heavy mineral studies is a conventional analysis based on the distribution of mineral species regardless of mineral variety. In contrast, high-resolution heavy mineral analysis (HRHMA) categorises the main mineral species accounting their colour varieties, internal zoning, inclusions and degree of roundness (Mange-Rajetzky, 1995; Lihou and Mange-Rajetzky, 1996; Mange and Wright, 2007b; Nie et al., 2012). The HRHMA method is especially useful for ultrastable minerals such as zircon and tourmaline since they, due to their high resistance, remain in multi-cycled deposits. The presence and proportions of highly rounded grains to euhedral ones yields information about source rock types, while comparison of mineral varieties in a profile enables more specific comparative provenance studies.

Conventional and HRHMA methods have been used in the current comparative study of heavy mineral assemblages from flysch sandstones of the Campanian-Maastrichtian part of the Ropianka Formation (Upper Cretaceous-Paleocene) and the prevailingly Kliva and Boryslav sandstone types of the Menilite Formation (Oligocene) from the northern margins of the Skole Nappe (Polish Flysch Carpathians). The results of conventional heavy mineral analyses of the Menilite Formation, already published by Salata and Uchman (2012), have currently been supplemented with HRHMA analyses and compared with new heavy mineral data from the Ropianka Formation. Such a combination allows refined comparative studies providing more specific data regarding the origins of heavy minerals from these formations. The data obtained provide a basis for further, more detailed, provenance research based on single-grain analyses (e.g., Eynatten and Dunkl, 2012; Nie et al., 2012).

\section{GEOLOGICAL BACKGROUND}

The Skole Nappe is situated on the north-east bend of the Carpathian orogenic arc (Fig. 1). It is formed of Lower Cretaceous-Lower Miocene deep-sea, mostly flysch strata that accumulated in the Skole Basin, which was at least about $150 \mathrm{~km}$ wide (Gagała et al., 2012), being a trough bordered by the European Platform in the north and by the Subsilesian ridge and slope in the south. The sedimentary fill of the basin has been folded and thrusted northwards during the Miocene. The Upper Cretaceous-Paleocene strata are distinguished as the Ropianka Formation (Kotlarczyk, 1978 and references therein) and called also the Inoceramian Beds in the older literature.
They are overlain by the upper Paleocene-Eocene deep-sea mudstone-dominated strata of the Variegated Shale Formation and the Eocene mudstones, sandstones and marls of the Hieroglyphic Formation (Rajchel, 1990). The Oligocene part is composed of the Menilite and Krosno formations (Fig. 2; Kotlarczyk, 1966; Kotlarczyk and Leśniak, 1990).

The Ropianka Formation was studied in the area of Husów and its vicinity (Fig. 3), where Wdowiarz (1949) distinguished lower, middle and upper levels in the Ropianka Formation (his Inoceramian Beds), which are altogether 500 m thick. Kotlarczyk (1978) subdivided the Ropianka Formation into the Cisowa Member (Turonian-Lower Campanian), Wiar Member (Lower Campanian-Lower Maastrichtian), Leszczyny Member (Lower Maastrichtian-Lower Paleocene) and Wola Korzeniecka Member (Paleocene). The deposits studied belong to the Wiar and Leszczyny members. The sections studied represent a proximal part of the depositional system, probably channel facies of a submarine fan, as in the case of sandstone-dominated sections (Manasterz, Husów - Patria, Husów - Biedroniówka, Nieważka), or more distal parts of the depositional system, such as lobes, interlobes or fan fringes (Husów - Gaj, Husów Bakkowiec, Husów - Bagnisty Stream, Rzeki - Gąszcz Stream, Tarnawka - leśniczówka A, B, Tarnawka 1-5, Tarnawka Quarry). These strata were deposited by turbidity currents or other density-flow currents. The outcrops belong to the Marginal Thrust Sheet, Husów Thrust Sheet and the Hadle Kańczudzkie-Chmielnik Thrust Sheet (Figs. 3-6). The Husów - Gaj section is dated to the Gansserina gansseri Zone (Upper Campanian-Lower Maastrichtian) (Gasiński and Uchman, 2009), while the Bakowiec section belongs to the Abathomphalus mayaroensis Zone of the Upper Maastrichtian (Gasiński and Uchman, 2011). The Tarnawka 2 section represents the same zone as the latter (A. Gasiński and A. Uchman, pers. comm., 2013).

The Menilite Formation is characterized by dark, mostly black or brown shales, which accumulated on the deep-sea, periodically anoxic flysch basin floor (Kotlarczyk and Uchman, 2012 and references therein). The shales contain horizons of chert, marl, limestone and diatomite, and lithosome of sandstone (Kotlarczyk and Leśniak, 1990; Kotlarczyk et al., 2006). The material studied derives mainly from the Boryslav and Kliva sandstones, which were deposited from gravity flows, mainly in channel zones. The sections studied are related to the Rzeszów and Łańcut channel zones (Kotlarczyk and Leśniak, 1990; Fig. 1). Their description and conventional heavy mineral characteristics are provided by Salata and Uchman (2012).

\section{SANDSTONE COMPOSITION}

Quartz is a dominant constituent of the Ropianka Formation sandstones, in the presently studied area, SE of Rzeszów. They contain feldspars, lithic fragments and subordinate amounts of mica, glauconite and organic debris. The sandstones represent mainly sublitharenite, subordinately subarkose types. They are mostly fine- to medium-grained and well- to moderately-sorted (Bromowicz, 1974). Among lithic fragments, sedimentary rocks represented mainly by limestones and siliceous rocks prevail. Additionally, igneous rocks such as fine-grained granitoids and, less frequent, dacites as well as metamorphic mica-schists and gneisses are also present (e.g., Bromowicz, 1974, 1986 and references therein). Pebbles of sedimentary rock are more abundant in the lower part of the Ropianka Formation while fragments or clasts of igneous and metamorphic rocks appear more frequently in its higher part (Bromowicz, 1974). According to Bromowicz (1986), the 


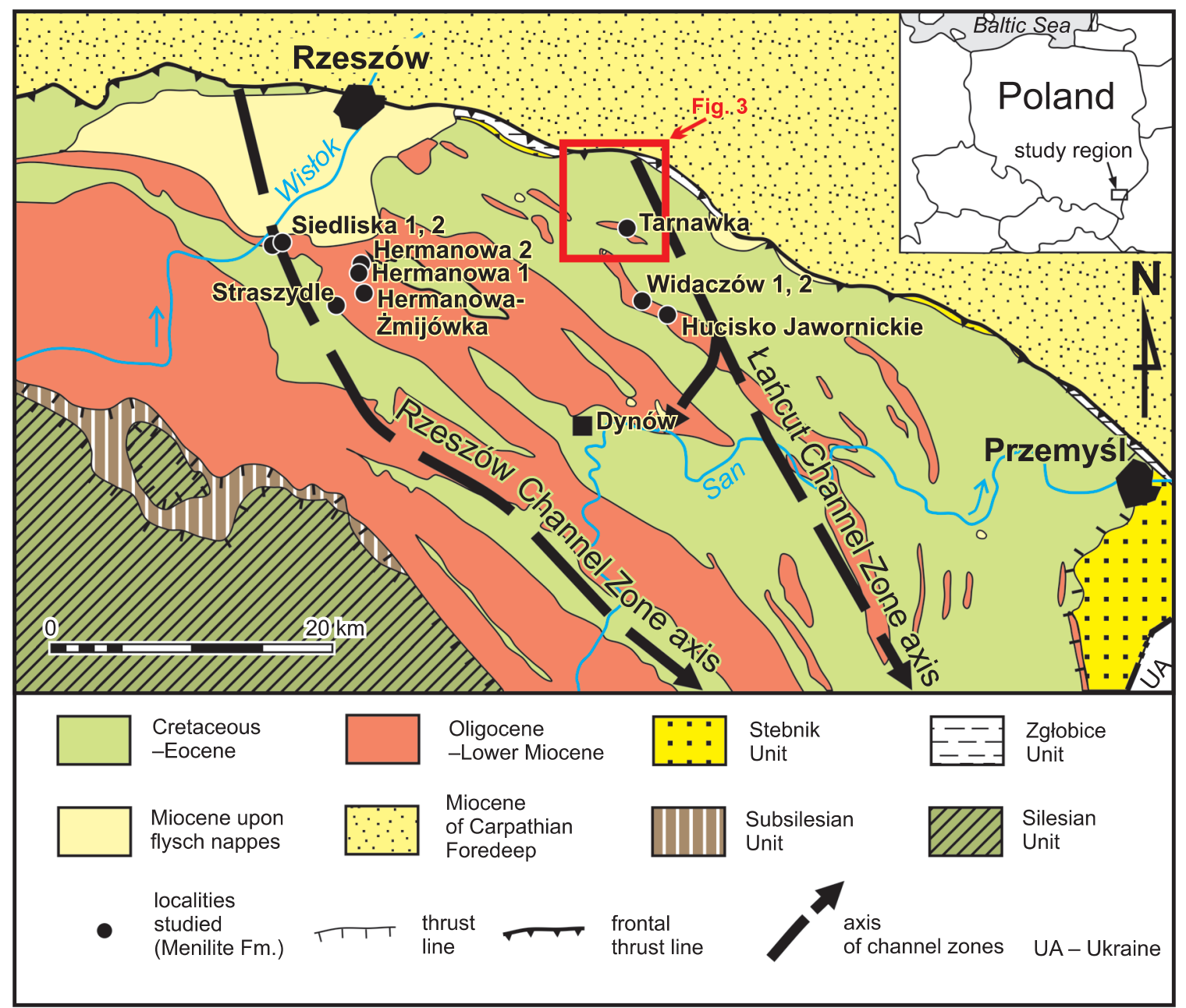

Fig. 1. General geological map showing location of the sections studied of the Menilite Formation (based on Kotlarczyk and Leśniak, 1990; modified by Kotlarczyk and Uchman, 2012; Salata and Uchman, 2012)

A more detailed map of the Husów area showing the location of the Ropianka Formation sections studied is included (Fig. 3)

contribution of igneous and metamorphic rocks in the source cordillera was distinctly smaller than the contribution of sedimentary rocks.

The Kliva Sandstone and lithologically similar Boryslav Sandstone (Oligocene) are mostly fine- to medium-grained and well- to moderately-sorted, although conglomeratic sandstones are also present. They are quartz-dominated; quartz is accompanied by feldspar and muscovite, and glauconite is often present. Among exotic clasts, coal clasts, chert and siltstone are common. The sandstones are poorly cemented, mostly massive, occasionally laminated (Żgiet, 1963; Kotlarczyk, 1966, 1976; Ślączka and Unrug, 1966).

\section{REMARKS ON PALAEOGEOGRAPHY}

The region studied, south-east of Rzeszów and south of Łańcut, refers to the northern marginal parts of the Skole Basin. To the north, the basin was surrounded by land or a shallow sea transitional to epicontinental basins (e.g., Książkiewicz, 1962; Bromowicz, 1974 and references therein). The palaeotransport directions indicate that the basin, for most of its development, was supplied mainly from its northwestern margin (e.g., Książkiewicz, 1962; Kotlarczyk, 1966, 1976; Ślączka and Unrug, 1966; Bromowicz, 1974; Kotlarczyk and Leśniak, 1990). Therefore, the area studied represents a region located close to the southern margin of the source area.

During accumulation of the Ropianka Formation in the area studied, sedimentation fluctuated from low energy deposition represented by shaly flysch, through sandy and normal flysch up to the appearance of submarine slides (Bromowicz, 1974). The fluctuations were related to activity along the northwestern source area termed Northern Cordillera(s) or Marginal Cordillera (e.g., Książkiewicz, 1962; Bromowicz, 1974, 1986). However, sea level changes and autocyclicity of the depositional system (probably deep-sea fans) should be also taken in the account.

The sediments of the Boryslav and Kliva sandstones were deposited mostly from gravity flows in channel zones extending south-east of Rzeszów and Łańcut, but similar deposits occur also outside the main channel zones (Kotlarczyk and Leśniak, 1990). According to Kotlarczyk and Leśniak (1990) 


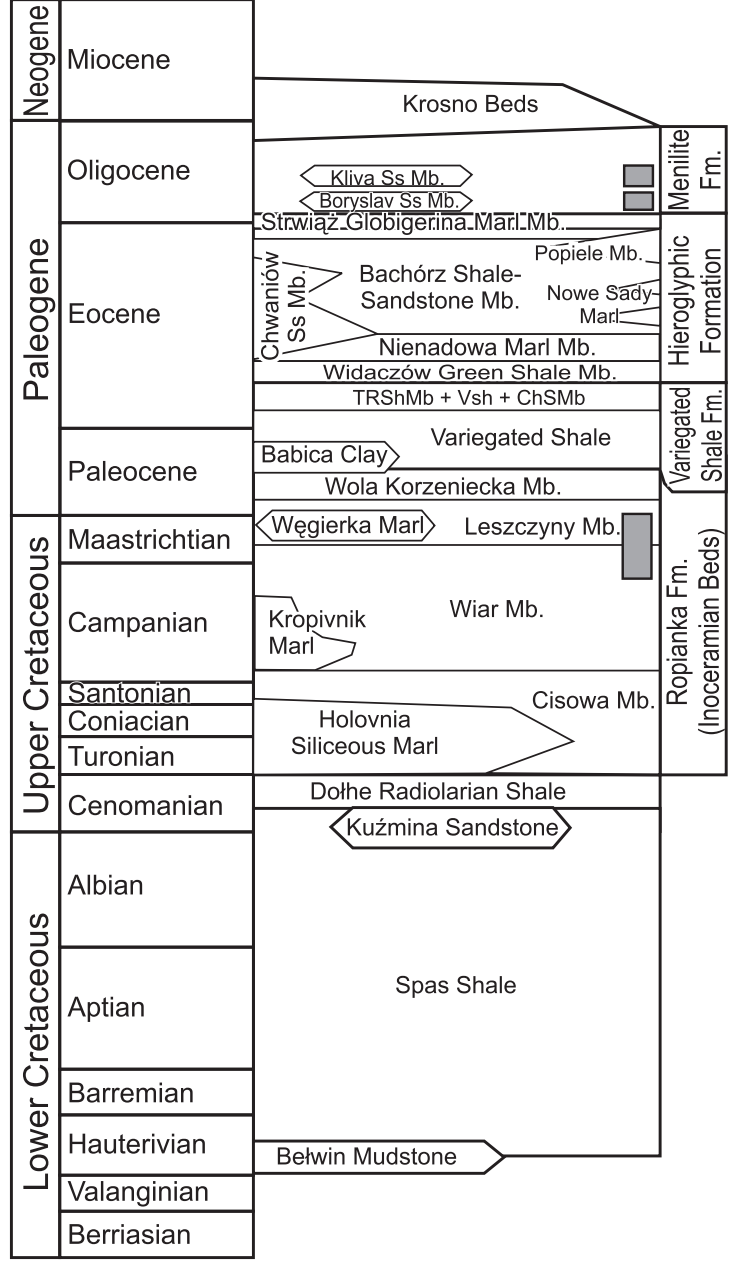

Fig. 2. Stratigraphy of the Skole Nappe (based on Gasiński and Uchman, 2009 and references therein) with indication of the time-span intervals studied of the Ropianka and Menilite formations (grey rectangles)

TRShMb - Trójca Red Shale Member, VSh - Variegated Shale, ChSMb - Chmielnik Striped Sandstone Member

and Kotlarczyk (1991), the channel zones were prolongation of canyons and rivers (Jucha, 1985). According to Kotlarczyk and Śliwowa (1963) and Kotlarczyk (1976), during sedimentation of the lower part of the Menilite Formation, the clastic material was transported by rivers from nearby land where gentle slopes, beaches and coastal sandy dunes prevailed, in contrast to the Campanian-Eocene interval, when, judging by the diversity and dimensions of exotic rock blocks (e.g., Bukowy, 1957; Kotlarczyk and Śliwowa, 1963; Skulich, 1986; Rajchel, 1990; Rajchel and Myszkowska, 1998), the source area included high cliffs.

\section{METHODOLOGY}

The sampled rocks of both formations are represented mostly by weakly or even almost unconsolidated fine- to medium-grained sandstones and sands (Figs. 4-6; see also Salata and Uchman, 2012). Sandstones sampled in the Husów - Gaj and Husów - Bakkowiec sections were well-cemented and required mechanical crushing. Otherwise, only gentle disintegration was needed for further preparations of the prevailing part of samples. This ensured that original grain shape would be preserved. The clastic material was cleaned with water to remove clays and sieved to obtain the $0.063-0.25 \mathrm{~mm}$ fraction, which was used for heavy mineral separation. Heavy minerals were separated using sodium polytungstate with $2.9 \mathrm{~g} / \mathrm{cm}^{3}$ density. Optical analyses were carried out on grain mounts in Canada balsam. 200 to 300 transparent, non-micaceous grains were counted according to the ribbon method and shown as number percentages (Galehouse, 1971). This conventional method was followed by the high resolution heavy mineral analysis (HRHMA) applied to zircon and tourmaline populations. The sum of at least 75 grains of each species were counted. Colourless, pink to purple and zonal colourless and zonal pink varieties of zircon and brown, green, blue, pink and patchy and zonal tourmaline colour varieties were established as the chief categories. In each colour variety those minerals were categorised in terms of rounding to three main groups representing rounded, subrounded and angular (including euhedral and pieces of euhedral) grains. The roundness degree was estimated according to the visual scale of Powers (1953). The group of euhedral zircon was additionally subdivided into zircons forming short or long prisms. Thirty six samples from the Ropianka Formation were studied using conventional and HRHMA methods and 36 samples of the Menilite Formation by means of the HRHMA method. The counting has not revealed significant differences in frequencies of zircon and tourmaline varieties between samples taken in outcrops stratigraphically and geographically located close to each other. Taking this into consideration and to overcome misleading differences resulting from sorting processes, the HRHMA data are shown as mean percent values of mineral varieties calculated for samples representing outcrops stratigraphically and geographically located near to each other. The calculated standard deviations of mineral contents between samples (s) were: $s<5$ for content ranges of $10-90 \%$; $s<2$ for content ranges of $1-5 \%$ and $s<0.3$ for the range lower than $1 \%$. The HRHMA data of the Ropianka Formation shown in suitable figures were grouped as follow: Gaj (sample from Husów - Gaj); Patria area (samples from Husów - Patria and Bąkowiec); Husów (samples from Husów Biedroniówka, Husów - Centrum, Husów - Dół); Tarnawka L. (samples from Tarnawka - leśniczówka A and B); Rzeki area (samples from Husów: the Bagnisty Stream and Rzeki: the Gaszcz Stream); Nieważka (sample from Nieważka); Tarnawka (samples from Tarnawka Quarry and Tarnawka 1-5); Manasterz (samples from Manasterz). Sample grouping shown in figures showing the HRHMA data of the Menilite Formation corresponds to profiles sampled by Salata and Uchman (2012). To avoid misleading differences emerging from the hydraulic behaviour of minerals, heavy mineral assemblages occurring only in fine- to medium-grained deposits were taken into account for current comparative studies. Therefore, the minerals from very-fine grained sandstones of the Hermanowa $1 \mathrm{sec}-$ tion of the Menilite Formation (Salata and Uchman, 2012) were excluded from the current comparative studies.

\section{RESULTS}

\section{CONVENTIONAL HEAVY MINERAL STUDY}

Heavy mineral assemblages of the Campanian-Maastrichtian part of the Ropianka and Menilite (Oligocene) formations in terms of mineral species are very similar. Zircon, tourmaline, 


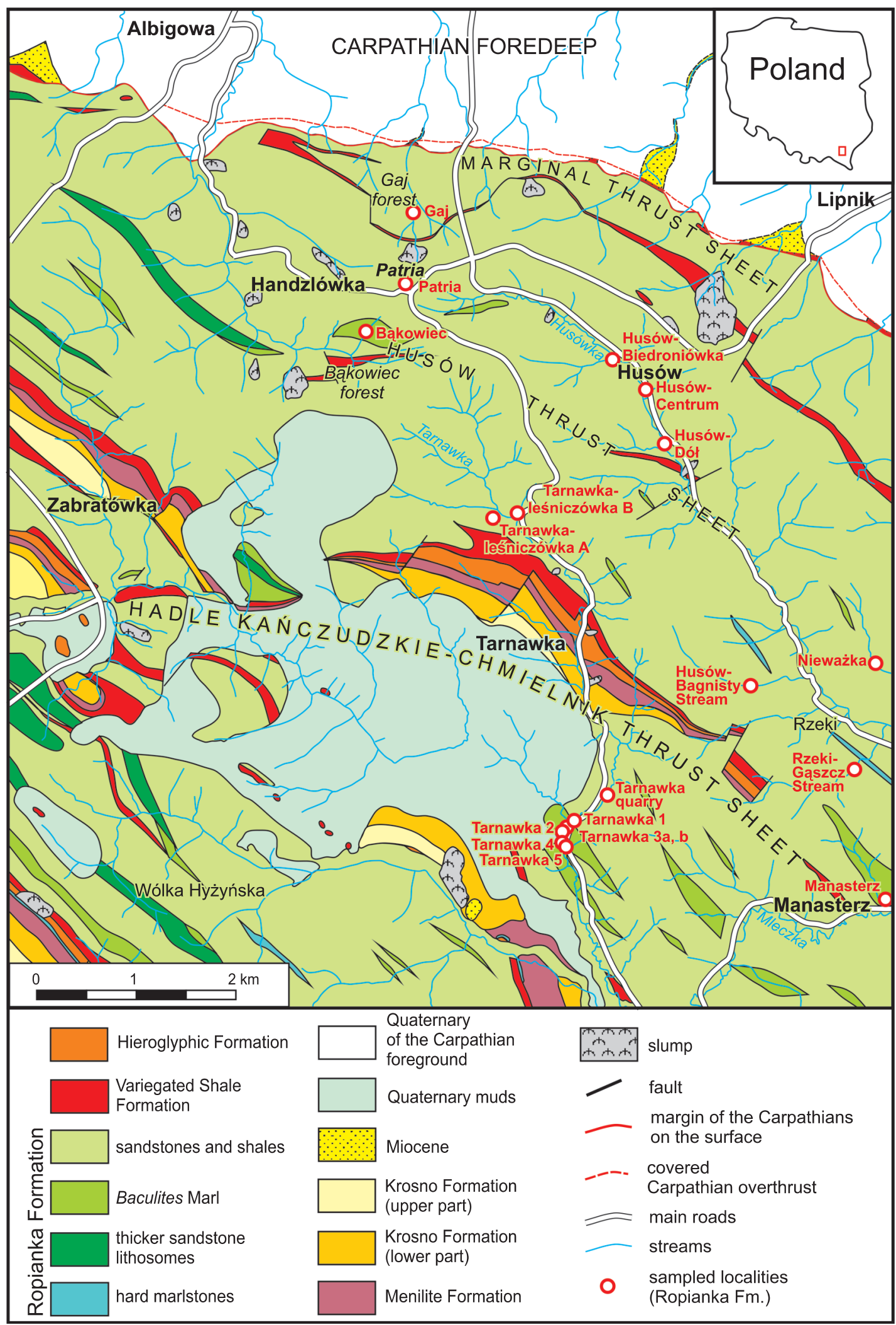

Fig. 3. Geological map of the Husów area (based on Wdowiarz, 1949; description of lithostratigraphic units modified according to Salata, 2013c) with indication of the sections studied of the Ropianka Formation 


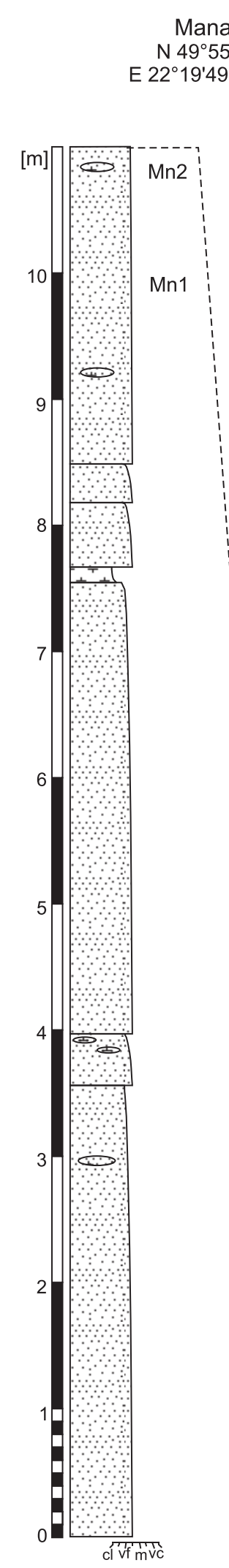

Manasterz N 49 $55^{\prime} 20.57^{\prime \prime} ; \quad$ [m] E 22 19'49.62"; $\pm 3 \mathrm{~m}$
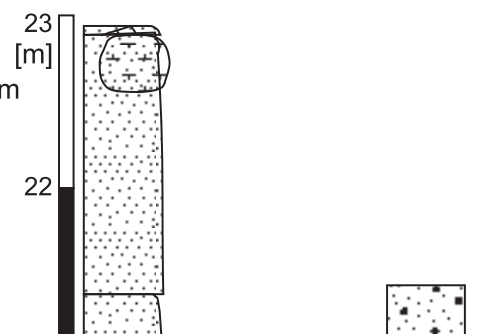

conglomeratic

sandstone

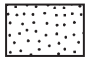

calcareous sandstone

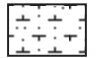

sandy

marlstone

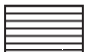

siltstone

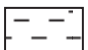

mudstone

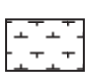

marlstone

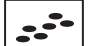

coal clasts

$\sim$ ripple cross

lamination

Mn3

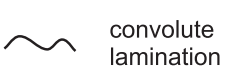

Mn1 sample

Tarnawka leśniczówka $A$

N 4957'46.56"; E 22 18'23.82"; \pm 3 m

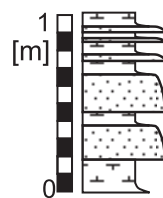

$\operatorname{Tr} 81$

Tarnawka -

leśniczówka $B$

N 4957'45.24"; E 22¹6'9.6"; \pm 5 m

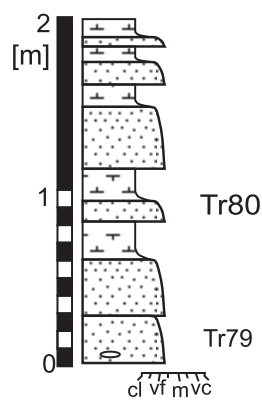

Fig. 4. Sampled profiles of the Ropianka Formation in the Husów Thrust Sheet

Grain-size scale: cl - clay, vf - very fine sand, m - medium sand, vc - very coarse sand rutile, garnet, kyanite and staurolite are typical minerals of both formations, while other mineral species are subordinate (Fig. 7). However, there are some differences in mineral frequencies. The Ropianka Formation displays relatively higher amounts of zircon, garnet and apatite while the Menilite Formation contains comparatively more kyanite and staurolite and almost lacks apatite (Fig. 7). Besides, individual grains of hornblende were found only in the Ropianka Formation, while the Menilite Formation contains locally present andalusite, which was not found in the Ropianka Formation. The zircon-tourmaline-rutile index value $($ zircon + tourmaline + rutile $=$ ZTR; Hubert, 1962) varies across a broad range of $27-95 \%$ (mean value $63 \%$ ) and $29-55 \%$ (mean value $43 \%$ ) in the Ropianka and Menilite formations, respectively. The Ropianka Formation, in relation to the Menilite Formation, shows higher amounts of the ZTR, resulting mainly from elevated zircon frequencies (Figs. 8 and 9).

To check if any correlation exists between ultrastable minerals, expressed as the content of ZTR and garnet, staurolite and kyanite (the three main constituents outside zircon, tourmaline and rutile) the Pearson's correlation coefficient $(r)$ was applied. This index not only shows the strength of a linear relationship of a rank of values but also shows its direction. A positive correlation ( $r$-values from 0 to 1 ) informs that an increase in one variable is accompanied by an increase in the second one. A negative correlation ( $r$-values from 0 to -1 ) indicates an increase in one variable accompanied by a decrease in the second one. The closest to 1(-1) a value of the correlation coefficient, the better is the relationship between variables considered.

A strong negative correlation between the ZTR value and garnet content $(r=-0.90)$ and a moderate negative correlation between ZTR and staurolite content $(r=-0.54)$ is present in the Ropianka Formation. This means that with decreasing ZTR, the content of garnet and staurolite increases (Fig. 9A, B). No correlation exists between the ZTR value and kyanite content in this formation ( $r=$ -0.18 ; Fig. 9C). In the Menilite Formation, a weak (negative) correlation concerns only ZTR and garnet $(r=$ -0.37 ). In the case of staurolite and kyanite from the Menilite Formation, 


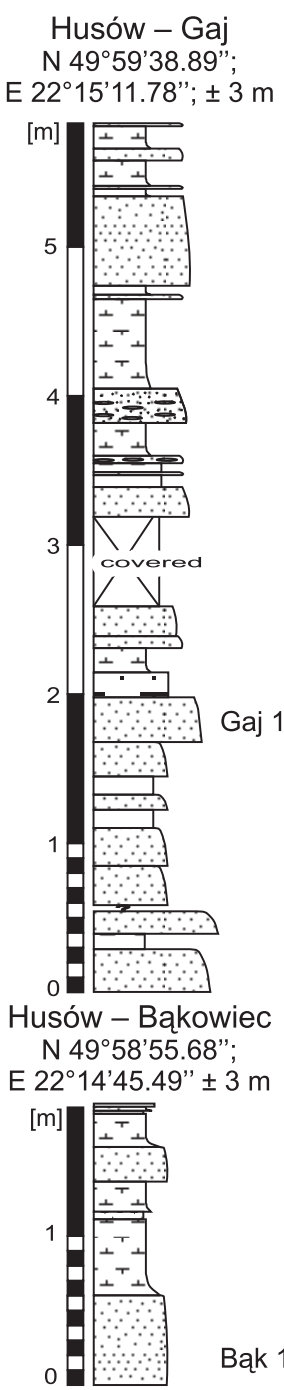

Husów - Patria N 49 $59^{\prime \prime} 10.36 "$ E $22^{\circ} 15^{\prime} 5.74^{\prime \prime} ; \pm 3 \mathrm{~m}$

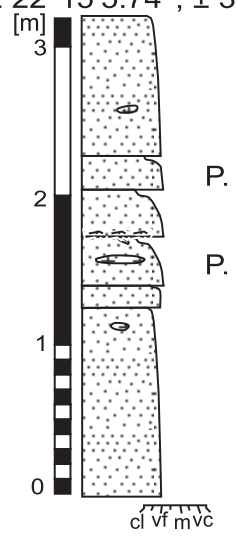

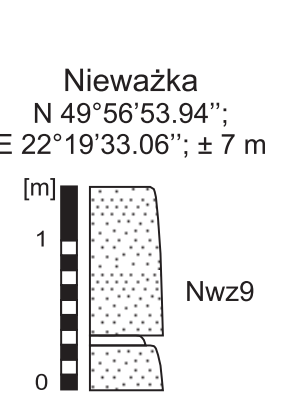

Husów -

Biedroniówka

N 49 $58^{\prime} 42.77$ ",

E 22०17'6.42"; $\pm 3 \mathrm{~m}$

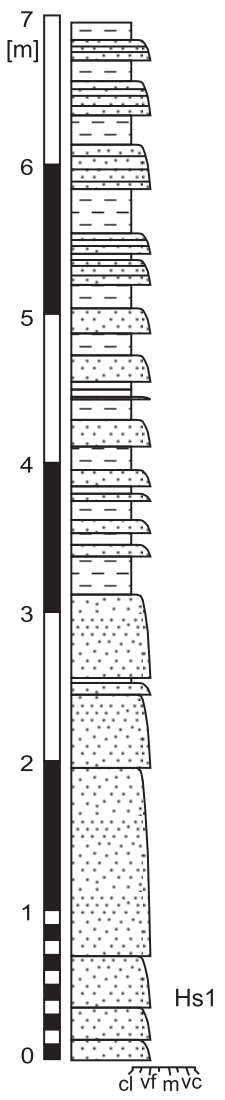

Husów -

Bagnisty Stream

N 4956'41.64"; E 22¹8'18.00"; \pm 9 m

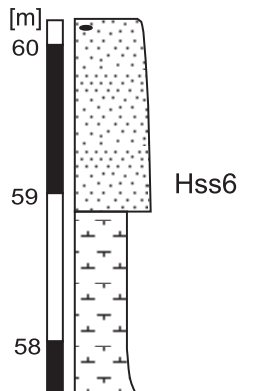

Rzeki -

Gąszcz Stream

N 49 56'9.24".

Centrum

49०58'31.86";

E 22'17'22.56"; \pm 9 m
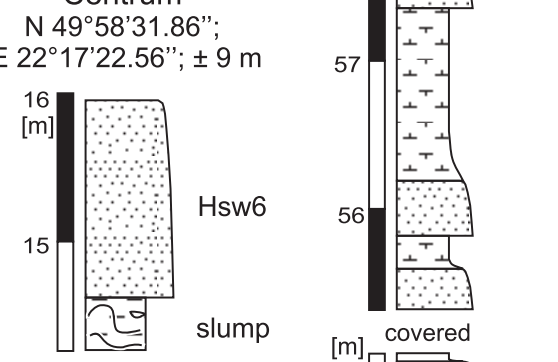

$[\mathrm{m}]$ covered

E $22^{\circ} 19^{\prime} 24.42^{\prime \prime} ; \pm 6$ m

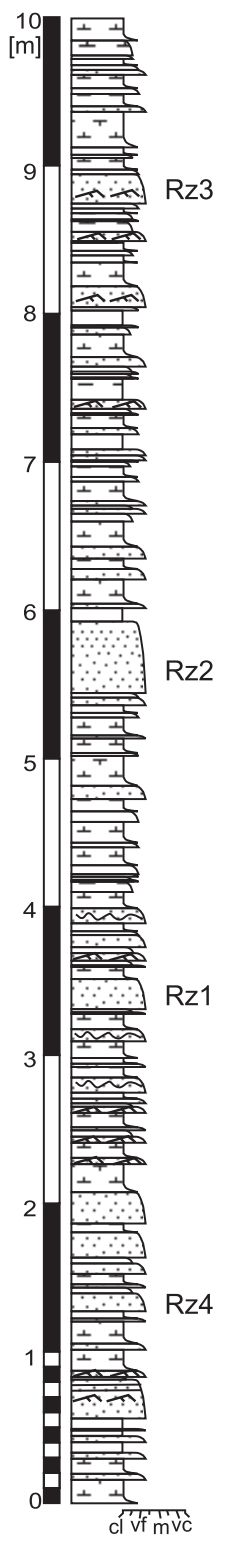

Fig. 5. Sampled profiles of the Ropianka Formation in the Marginal Thrust Sheet (section Husów - Gaj) and the Husów Thrust Sheet 
Tarnawka 2

N 49 $55^{\prime} 50.53^{\prime \prime}$

E 22॰16'35.89"; \pm 3 m

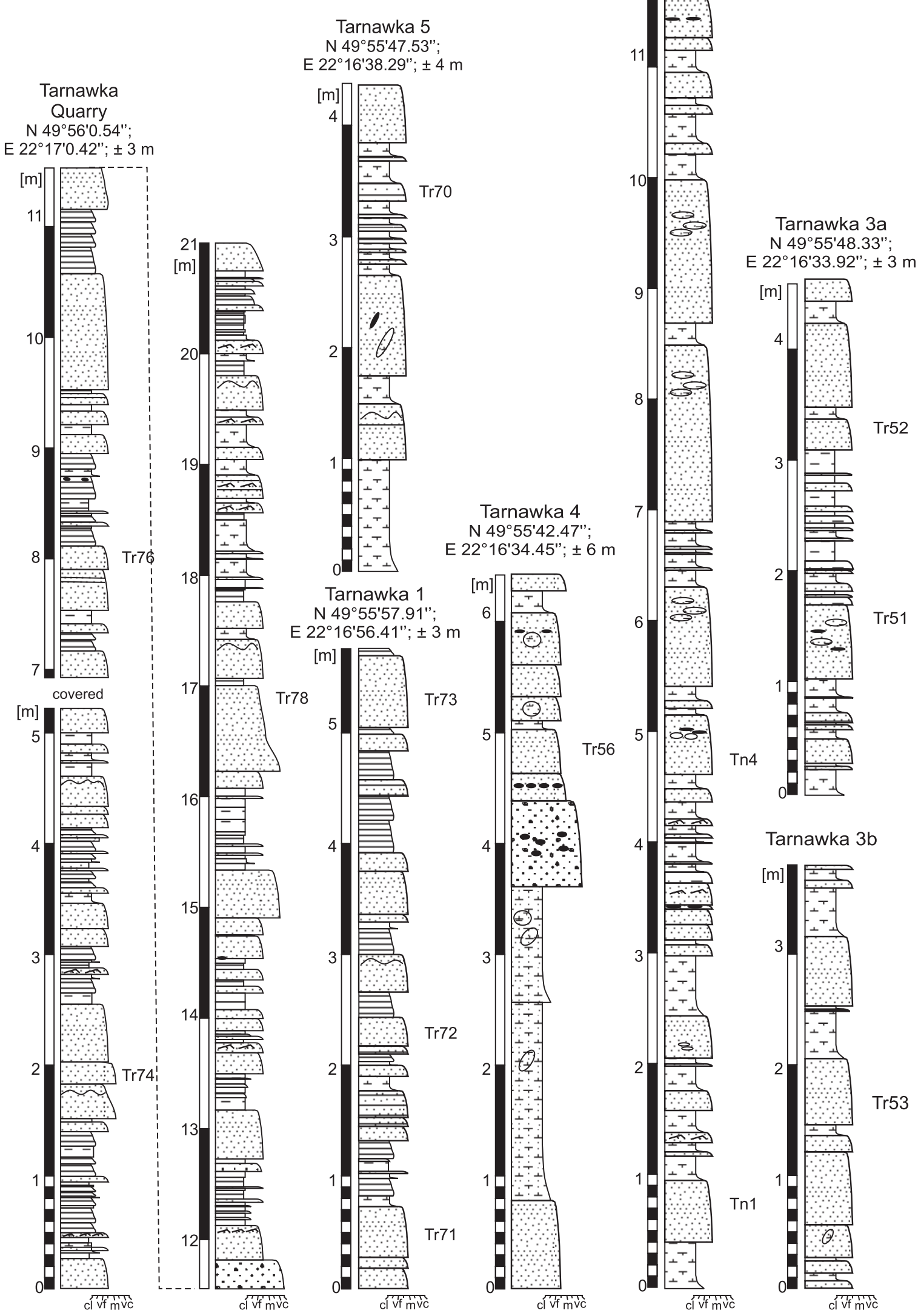

Fig. 6. Sampled profiles of the Ropianka Formation in the Hadle Kańczudzkie-Chmielnik Thrust Sheet 
Ropianka Formation

[\%]

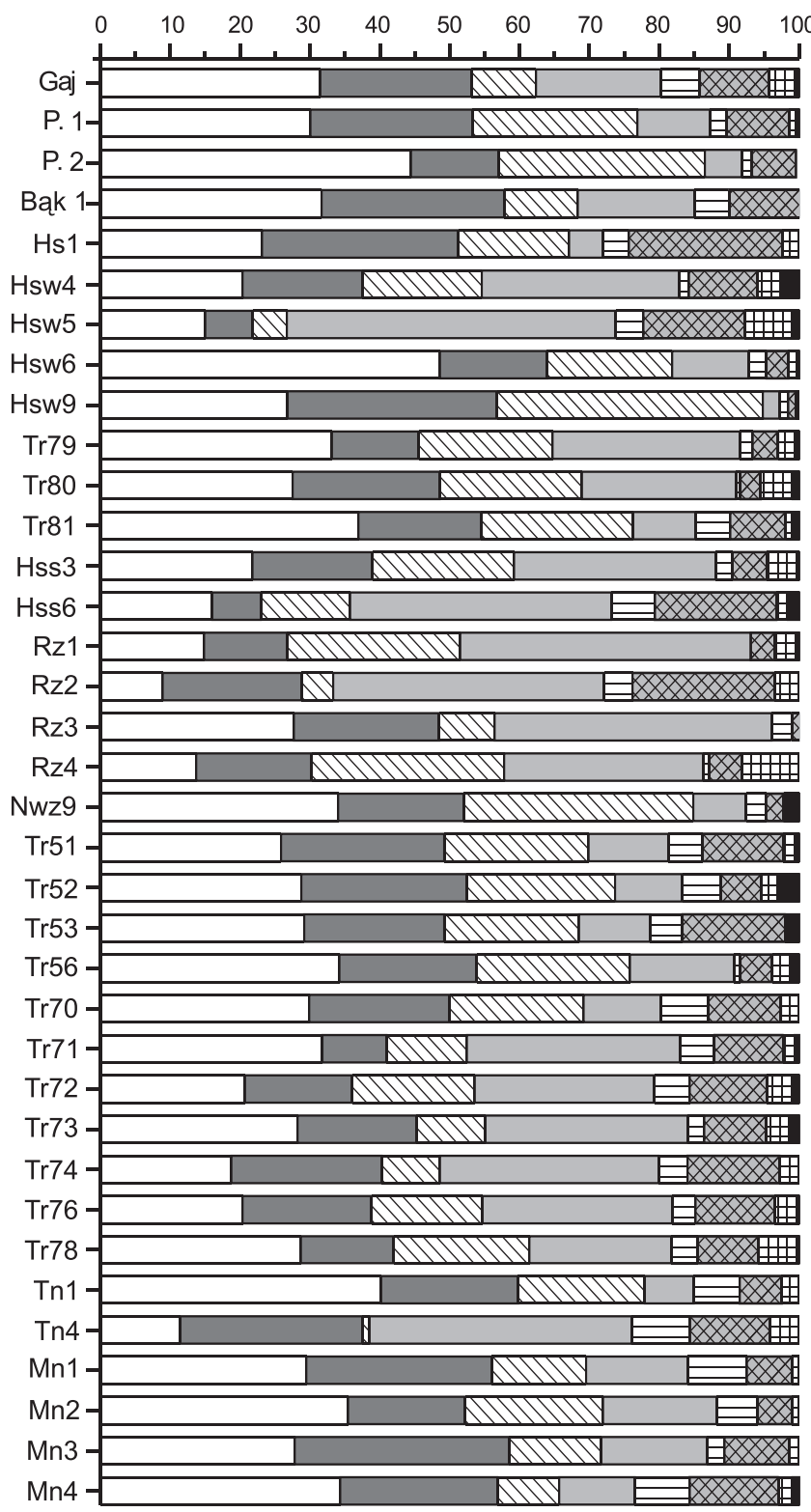

Menilite Formation

[\%]

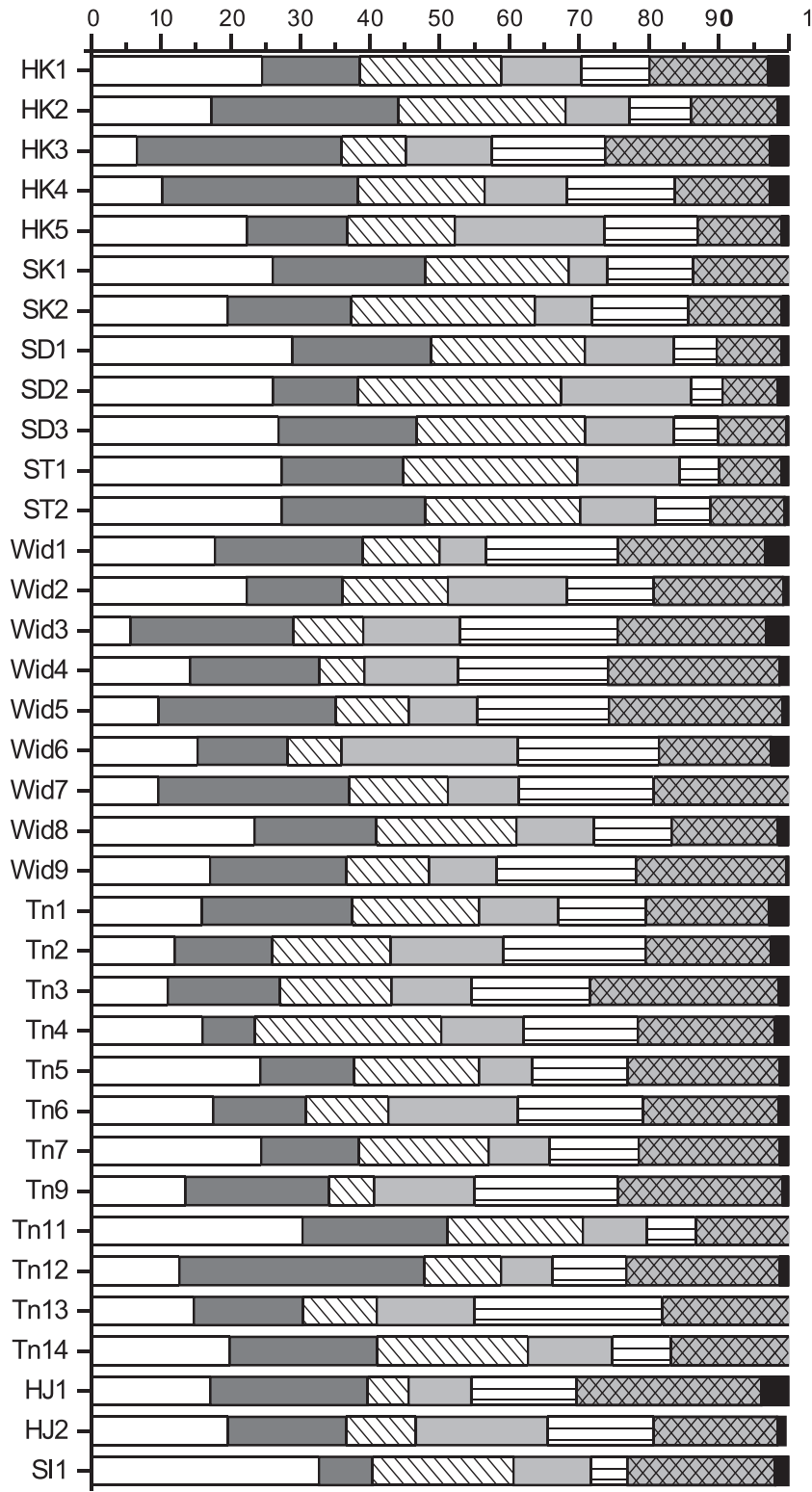

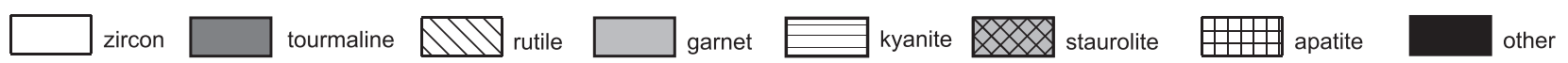

Fig. 7. Frequencies of heavy minerals in the Ropianka Formation compared to frequencies of minerals from selected samples of the Menilite Formation (data dealing with minerals of the Menilite Formation taken from Salata and Uchman, 2012)

the relationship is reversed: the higher ZTR value the higher the amounts of these minerals, which is reflected in relatively strong and weak positive correlations of $r=0.89$ and $r=0.28$ respectively (Fig. 9B, C).

Although there are some differences regarding mineral contents between the formations in question, the mineral habits are the same. Highly rounded, subrounded and euhedral grains are present in all heavy mineral species. Rounded and subrounded grains prevail in the zircon, tourmaline (Figs. 10 and 11), and rutile populations. Garnet and staurolite, in both formations, most often occur as irregular, angular fragments, which may be pieces of rounded as well as euhedral grains. However, the presence of whole rounded and euhedral garnet was also detected. The same concerns the remaining minerals. In almost all mineral species features of dissolution processes, visible mainly as facets, hacksaw terminations or etch pits on grain surfaces, are present. The dissolution microtextures are advanced to various degrees, ranging from light to incipient in skeletal crystals. Nevertheless, mineral fragments with smooth fracture surfaces, and euhedral crystals, not significantly affected by dissolution processes, are also present (see also Salata and Uchman, 2012). 


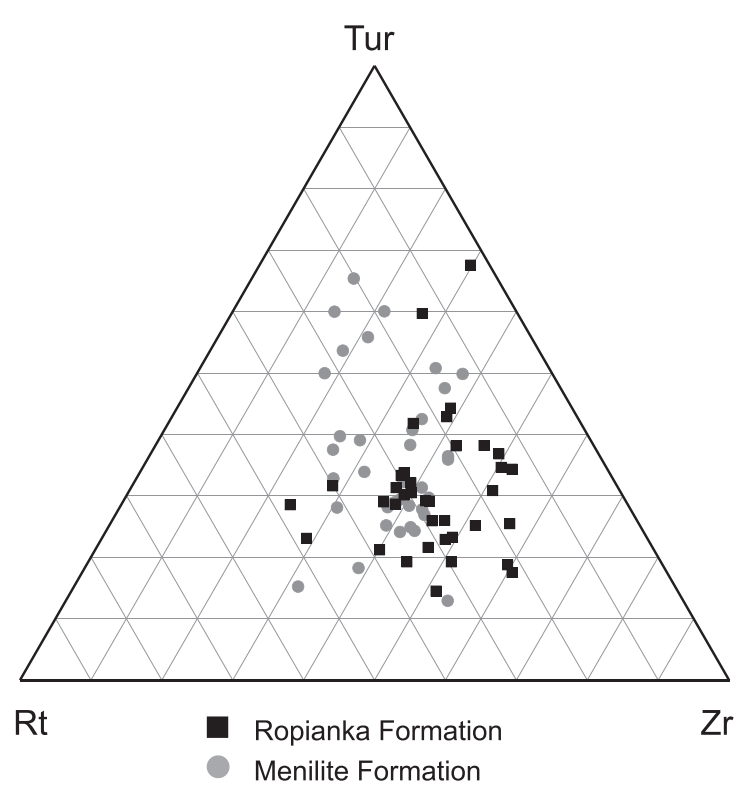

Fig. 8. Mutual proportions of zircon, tourmaline and rutile shown in the tourmaline-rutile-zircon triangle

\section{HIGH-RESOLUTION HEAVY MINERAL ANALYSES}

Zircon varieties are almost identical in both formations studied (Fig. 10): rounded colourless varieties clearly prevail comprising from 60 to $90 \%$ of the zircon population. Subrounded colourless zircon frequencies mostly vary in the range of $10-20 \%$ in both formations, rarely reaching $5-10 \%$ in the Ropianka Formation and $20-30 \%$ in the Menilite Formation. Euhedral colourless zircon constitutes less than $5 \%$, occasionally reaching ranges of $10-20 \%$ and $5-10 \%$ in the Ropianka and Menilite formations, respectively. Both elongated and short prisms of colourless zircon are present, although elongated prisms are more frequent than short ones. Euhedral, long zircon prisms are more frequent in the Ropianka Formation than in the Menilite Formation, reaching the range of $10-20 \%$ in the Tarnawka - leśniczówka and Patria area profiles. Pink to purple zircon, without visible zonation, is represented by rounded grains $(1-5 \%)$, while subrounded and euhedral grains are rare $(<1 \%$ in individual samples). Zircon with oscillatory zonation is present mostly as rounded or subrounded colourless grains and comprises usually $1-5 \%$ or $<1 \%$, exceptionally $10-20 \%$, while euhedral zonal as well as pinkish zonal zircon is very scarce in both formations ( $<1 \%$ or occasionally $1-5 \%$; Fig. 10 ).

Tourmaline varieties, like zircon, display typological similarity in both Ropianka and Menilite formations (Fig. 11). The most numerous group in both formations comprises rounded (up to $80 \%$ ) or subrounded (up to $50 \%$ ), brownish, visually not zonal tourmaline. Greenish, rounded tourmaline comprises mostly $5-10 \%$ (occasionally $1-5 \%$ or $10-20 \%$ ), while subrounded grains occur in amounts usually from 5 to $10 \%$ or $1-5 \%$, reaching the range of $10-20 \%$ only in the Menilite Formation. Zonal and "patchy" ( $1-5 \%$ and $<1 \%)$, blue and pink (both $<1 \%$ ) tourmaline is scarce and represented mainly by rounded or subrounded grains. Euhedral tourmaline is not common and is present dominantly as the brown variety (up to $20 \%$ ), while other colour varieties of euhedral tourmaline usually do not reach $1 \%$ in both formations (Fig. 11).

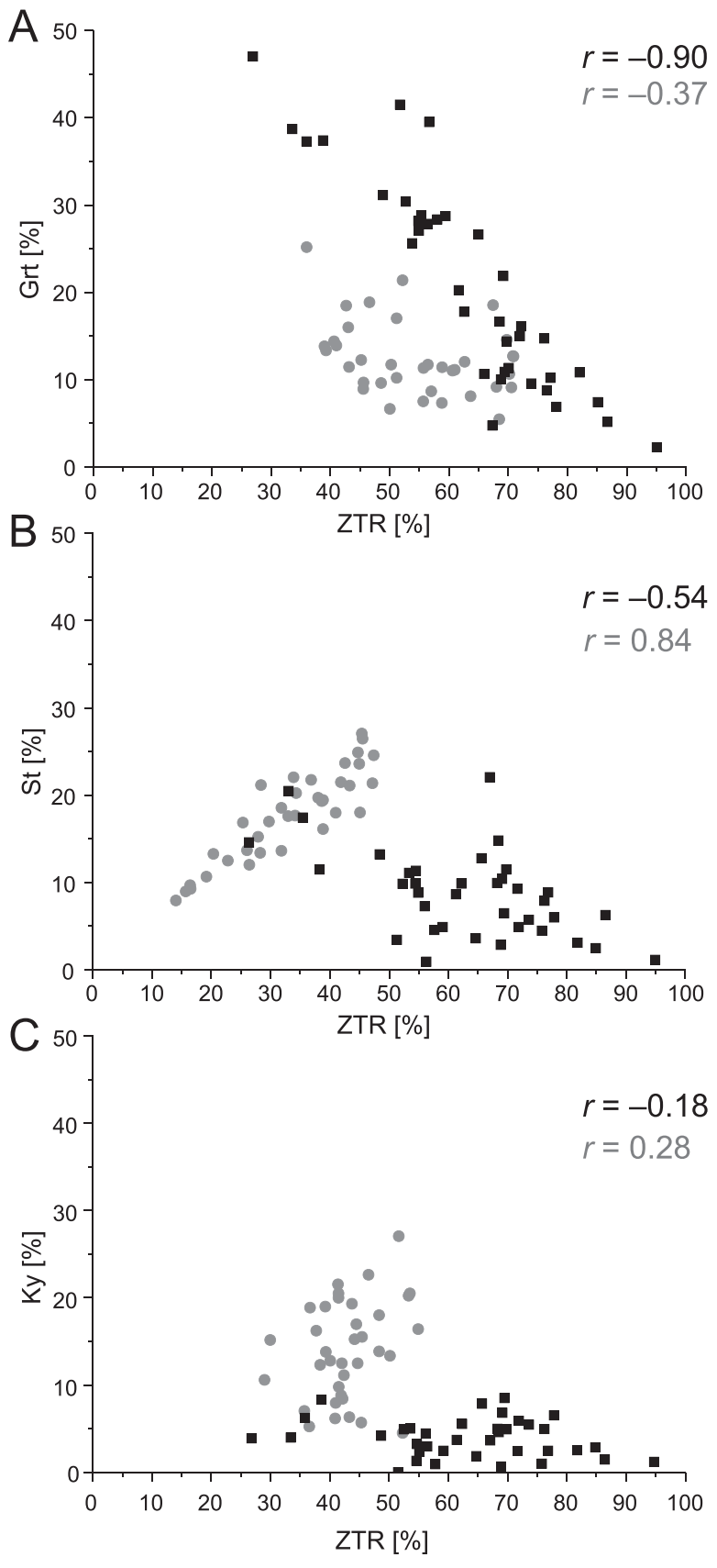

Fig. 9. Correlation between A - garnet (Grt), B - staurolite (St) and C - kyanite $(\mathrm{Ky})$ and zircon + tourmaline + rutile (ZTR) values for the Menilite (Boryslav and Kliva sandstones) and the Ropianka formations; $r$ - Pearson's correlation coefficient

\section{DISCUSSION}

The compositional similarities of the heavy mineral assemblages studied as well as the resemblance of the zircon and tourmaline varieties suggest that both the formations studied were supplied from lithologically similar source area(s). Additionally, the occurrence of rounded along with subrounded and euhedral zircon and tourmaline varieties in both formations suggests that these sediments have a mixed polycyclic and first-cy- 


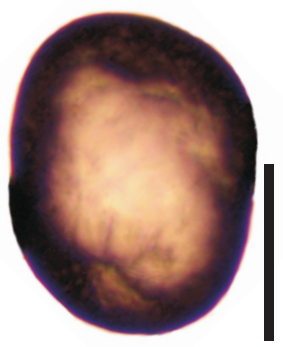

rounded colourless

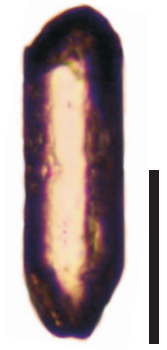

subrounded colourless

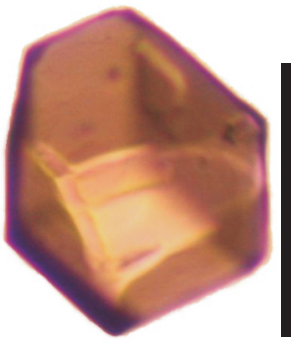

euhedral, short prismatic colourless

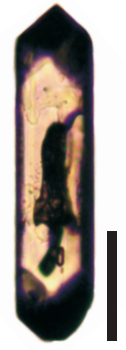

euhedral, long prismatic colourless

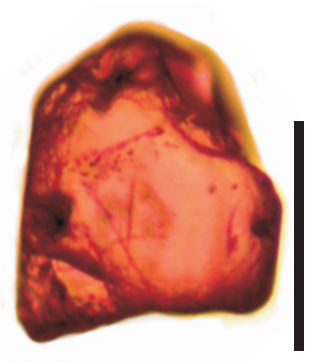

subrounded pink

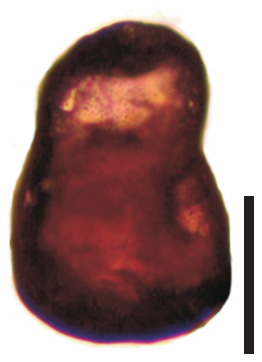

rounded pink

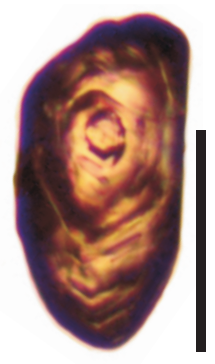

rounded zonal

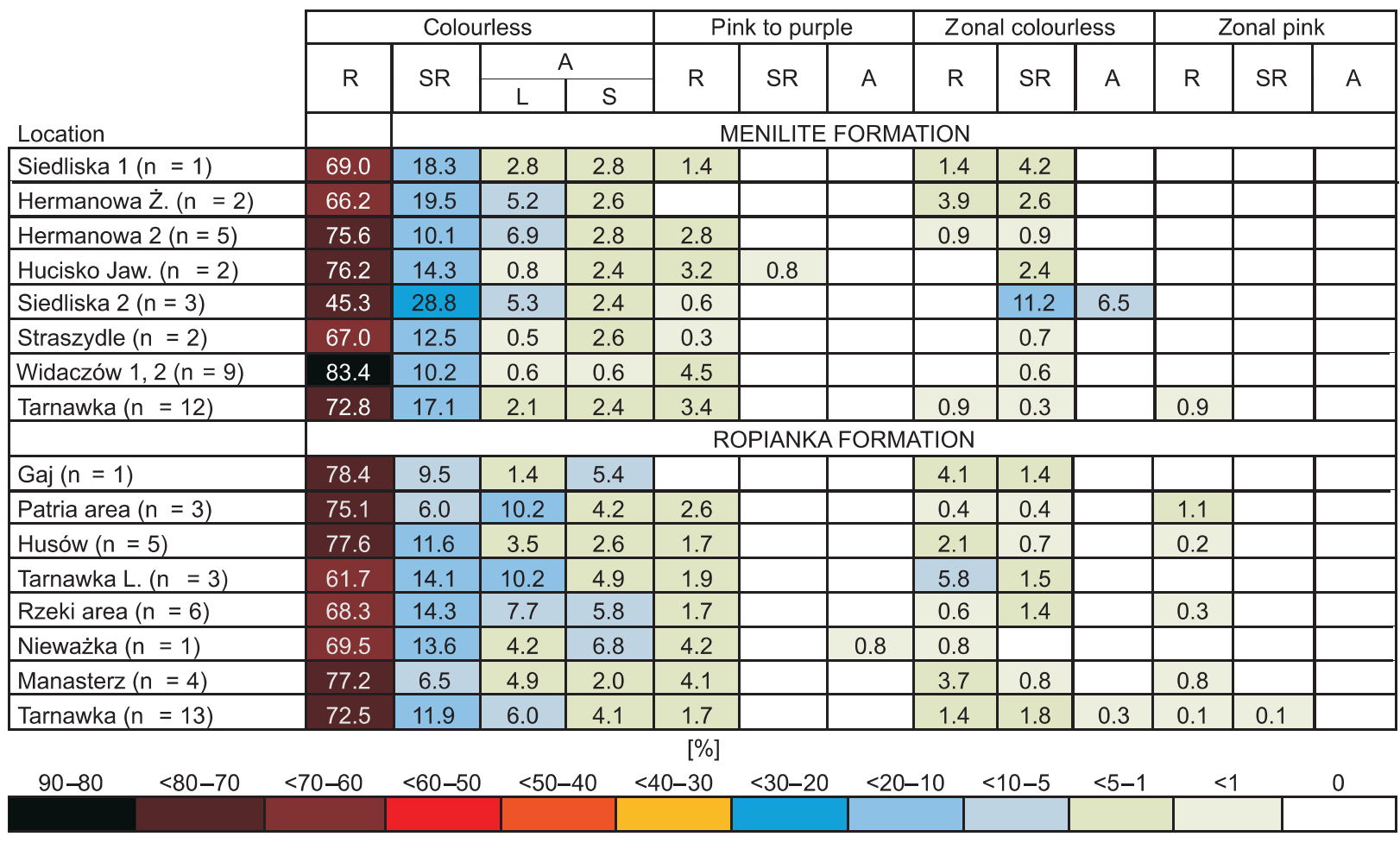

Fig. 10. Representative images of the most typical zircon varieties and frequencies of them in the Ropianka and Menilite formations

Numbers in the table denote mean percent values; $n$ - number of samples studied; R - rounded grains; SR - subrounded grains; A - angular grains (euhedral crystals and fragments); scale bars are $0.1 \mathrm{~mm}$ long; see "Methodology" section for further explanation 


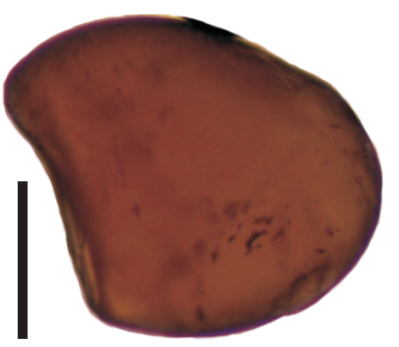

rounded brown

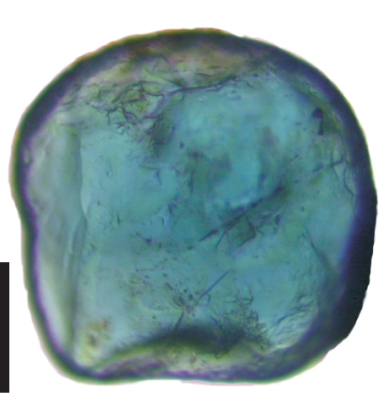

rounded blue

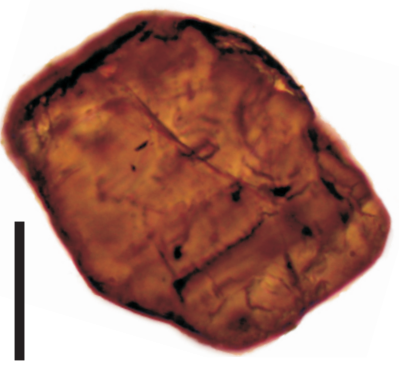

subrounded brown

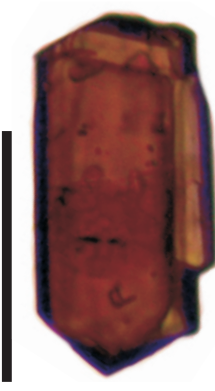

angular, euhedral brown

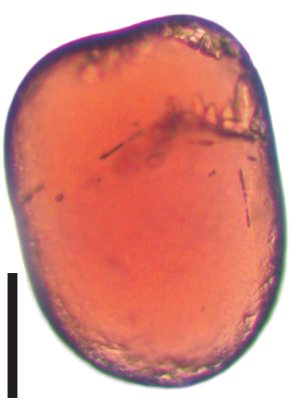

rounded pink

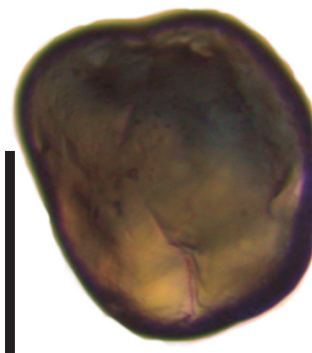

rounded green

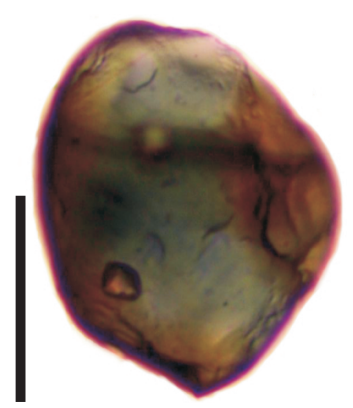

rounded zonal

\begin{tabular}{|c|c|c|c|c|c|c|c|c|c|c|c|c|c|c|c|}
\hline \multirow[b]{3}{*}{ Location } & \multicolumn{3}{|c|}{ Brown } & \multicolumn{3}{|c|}{ Green } & \multicolumn{3}{|c|}{ Blue } & \multicolumn{3}{|c|}{ Pink } & \multicolumn{3}{|c|}{ Patchy and zonal } \\
\hline & $\mathrm{R}$ & SR & A & $\mathrm{R}$ & SR & A & $\mathrm{R}$ & SR & A & $\mathrm{R}$ & SR & A & $\mathrm{R}$ & SR & $\mathrm{A}$ \\
\hline & \multicolumn{15}{|c|}{ MENILITE FORMATION } \\
\hline Siedliska $1(n=1)$ & 32.0 & 20.0 & 12.0 & 16.0 & 12.0 & & 4.0 & & 4.0 & & & & & & \\
\hline Hermanowa Ż. $(n=2)$ & 22.0 & 45.0 & 10.0 & 3.7 & 11.0 & 3.7 & & & & 0.9 & & & & 3.7 & \\
\hline Hermanowa $2(n=5)$ & 51.0 & 26.5 & 2.0 & 8.2 & 6.5 & 0.8 & 0.4 & & & 0.4 & 0.4 & & 2.4 & 1.2 & \\
\hline Hucisko Jaw. $(\mathrm{n}=2)$ & 60.9 & 19.6 & & 9.4 & 4.3 & 0.7 & 1.4 & 0.7 & & & & & 2.2 & 0.7 & \\
\hline Siedliska $2(n=3)$ & 31.6 & 41.2 & 11.0 & 6.6 & 7.4 & 1.5 & 0.7 & & & & & & & & \\
\hline Straszydle $(n=2)$ & 65.0 & 25.1 & 0.7 & 7.1 & 4.1 & & 0.5 & 0.5 & & & & & & & \\
\hline Widaczów 1, $2(n=9)$ & 57.4 & 29.3 & 0.8 & 7.0 & 1.7 & & 0.8 & 0.8 & & & & & 2.1 & & \\
\hline \multirow[t]{2}{*}{ Tarnawka $(n=12)$} & 63.6 & 22.2 & 1.5 & 6.9 & 2.5 & 1.8 & & & & 0.7 & 0.4 & & 0.4 & & \\
\hline & \multicolumn{15}{|c|}{ ROPIANKA FORMATION } \\
\hline Gaj $(n=1)$ & 71.7 & 13.3 & 5.0 & 5.0 & 3.3 & & 1.7 & & & & & & & & \\
\hline Patria area $(n=3)$ & 62.6 & 13.2 & 1.7 & 9.8 & 6.3 & 2.3 & 0.6 & 0.6 & & & & & 2.3 & 0.6 & \\
\hline Husów $(n=5)$ & 48.5 & 24.4 & 7.1 & 8.8 & 5.5 & 1.1 & 0.3 & 0.3 & & 0.3 & & 0.5 & 1.9 & 1.4 & \\
\hline Tarnawka L. $(n=3)$ & 32.0 & 23.8 & 16.8 & 5.3 & 12.7 & 5.3 & & 0.8 & 0.4 & & 0.8 & & 0.8 & 0.4 & 0.8 \\
\hline Rzeki area $(n=6)$ & 41.1 & 34.3 & 5.9 & 5.3 & 8.6 & 0.3 & 1.2 & & & & 0.3 & 0.3 & 0.9 & 1.5 & 0.3 \\
\hline Nieważka $(n=1)$ & 41.9 & 31.4 & 10.5 & 7.0 & 4.7 & 1.2 & & & & & & & 2.3 & 1.2 & \\
\hline Manasterz $(n=4)$ & 56.9 & 24.5 & 6.7 & 4.7 & 2.8 & & 0.8 & & 0.4 & & & & 2.8 & 0.4 & \\
\hline Tarnawka $(n=13)$ & 49.7 & 23.9 & 5.6 & 8.4 & 7.8 & 0.8 & & 0.3 & 0.2 & 0.1 & 0.4 & 0.4 & 0.8 & 0.8 & 0.2 \\
\hline $80-70$ & & $<60-50$ & $<50$ & & $<40-3$ & & -20 & $<20$ & & $<10-5$ & & & $<1$ & & 0 \\
\hline & & & & & & & & & & & & & & & \\
\hline
\end{tabular}

Fig. 11. Representative images of the most typical tourmaline varieties and frequencies of these in the Ropianka and Menilite formations

Other explanations and abbreviations as for Figure 10; scale bars are $0.1 \mathrm{~mm}$ long

cle provenance. However, since rounded grains prevail in these mineral populations, they seem to derive mainly from sedimentary rocks. Such a conclusion may be also drawn from the ZTR value, ranging widely from low to high values. However, the ZTR value alone may be misleading as it is largely controlled by the source rock composition. High ZTR values do not necessarily indicate delivery of multi-cycle sedimentary material since erosion of low-grade metasedimentary rocks, where zircon, tourmaline and rutile dominate as accessory minerals, may give the same index value (e.g., Garzanti and Andò, 2007). How- 


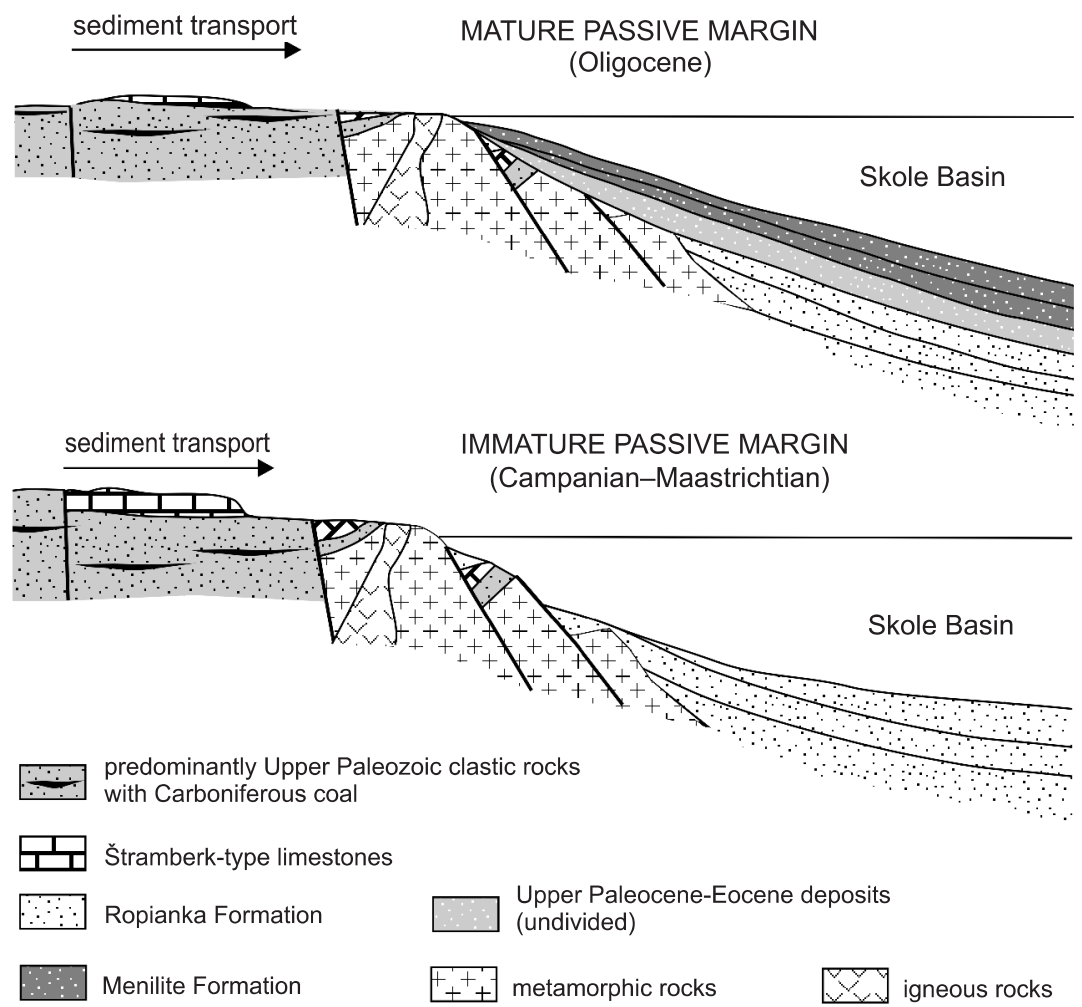

Fig. 12. Schematic models (not to scale) of development of the northern margin of the studied part of the Skole Basin during sedimentation of the Ropianka and Menilite formations

ever, the ZTR index is commonly used as an indicator of a degree of modification or maturity of heavy mineral assemblages.

It is striking that the ZTR values versus garnet and staurolite and kyanite content correlation trends are always negative in the Ropianka Formation, while in the Menilite Formation only ZTR/garnet relationship is negative (Fig. 9).

The negative correlations of ZTR values with garnet amounts, meaning that the lower the ZTR value the higher amount of garnet, may reflect first-cycle delivery of some part of garnet population to both formations. However, the correlation coefficient value closer to -1 for the ZTR-garnet pair in the Ropianka Formation (Fig. 9A) suggests a larger input of garnet coming directly from crystalline rocks during sedimentation of this formation than during Menilite Formation deposition. The ZTR and staurolite relationship in the Ropianka Formation displays the same negative trend as for ZTR-garnet, although the correlation is not as high as in the garnet case. This suggests that also staurolite in the Ropianka Formation may, to some extent, originate directly from its parent rocks. The same refers to kyanite, albeit the correlation of this mineral with ZTR, and thus the probability of its origin directly from parent rocks, is uncertain. The same negative trends of relationship between ZTR and garnet, staurolite and, to lesser extent, kyanite suggest that these minerals were delivered during the same sedimentary episode and originate from the same source rocks.

In case of the Menilite Formation the negative correlation visible only for the ZTR and garnet implies that garnet represents first-cycle delivery. However, the correlation is worse than in the Ropianka Formation. The positive correlation trends concern the ZTR and staurolite and kyanite content (Fig. 9B, C), which may indicate that staurolite and kyanite derive from sedi- mentary rocks or palimpsest sediments sensu McManus (1975), as the relationships should rather be reversed for first-cycle input. The same concerns the low correlation of garnet with the ZTR value. According to McManus's palimpsest definition, the garnet, staurolite and kyanite populations studied would accumulate at first on the basin shore or slope, mix with ZTR constituents delivered from sedimentary rocks and then would be redeposited to the basin together. Zircon, tourmaline, rutile, staurolite and kyanite display comparable resistance to weathering (e.g., Morton and Hallsworth, 1999 and references therein), which may explain the similar trend in their relationship to the ZTR values.

The primary heavy mineral signal of the source area, and thus the proposed view concerning mineral provenance based on the mineral relationships, may be easily obscured by changes in climate conditions controlling weathering of the eroded material prior to its final deposition in the Skole Basin. The Carpathian flysch basins remained in a temperate climatic zone (e.g., Kiessling et al., 2003) during the Late Cretaceous and Oligocene, although during the Cretaceous the climate was warm and humid, while during the Oligocene it was cool and humid (e.g., Zachos et al., 2001; Friedrich et al., 2005; Melinte, 2005; Soták, 2010; Kędzierski and Leszczyński, 2013 and references therein). Such a climatic change should reduce chemical weathering of primary heavy mineral suites as chemical weathering should be more intensive in a warm and humid climate. The content of garnet, kyanite and staurolite does not significantly differ between the formations studied, but those minerals display different relationships with the ultrastable ZTR suite. Moreover, apatite, despite a warm and humid environment strongly influencing its weathering (e.g., Turner and Mor- 
ton, 2007 and references therein), is present in the Ropianka Formation. However, there is a visible decrease in the apatite content and lack of hornblende in the Menilite Formation in comparison to the Ropianka Formation. The lack of amphibole is not surprising, since it is very unstable during burial diagenesis (e.g., Morton and Hallsworth, 1999, 2007; Turner and Morton, 2007 and references therein) but the significant decrease of apatite in the Menilite Formation is striking. Moreover, the remained apatite grains are mostly highly corroded, though only slightly corroded grains are infrequently present (Salata and Uchman, 2012). Such a coexistence of variously etched apatite indicates that the incipient corrosion of part of the apatite grains took place before its final deposition in the Skole Basin. The lack of apatite in the Menilite Formation has previously been attributed to a prolonged storage in the Skole Basin foreland prior to deposition in the basin (Salata and Uchman, 2012). Apatite is stable during burial diagenesis but it is sensitive to storage conditions in coversands in a subaerial environment (Morton and Hallsworth, 1999; Turner and Morton, 2007 and references therein). Therefore, if apatite was present in the source rocks, its lack in the Menilite Formation may be caused by weathering during a long storage period.

The impoverishment in apatite and hornblende caused by weathering during storage periods may result in a misleading interpretation of lithological change in a source area over time, though such a scenario should also be taken into account. According to this, initially (during the Ropianka Formation sedimentation) rocks rich in garnet, apatite and stable minerals (zircon, tourmaline, rutile) would be eroded and then (during the Menilite Formation sedimentation) rocks containing staurolite, kyanite and stable minerals became available. The change in source area petrography is also supported by the presence of andalusite only in the Menilite Formation. The assemblages composed of garnet, staurolite, kyanite and andalusite are characteristic of metamorphic bodies. Therefore, the remark on a change in source rocks petrography refers mainly to metamorphic rocks. Recent data on the chemical composition of garnet from the Ropianka and Menilite formations indicate its crystallisation mainly in metamorphic rocks of eclogite to amphibolite facies and in igneous rocks (Salata, 2013a, c), which supports the metamorphic origin of garnet in both formations deposits and the existence of metamorphic bodies in the source area. Judging by the similarities in composition of garnet from the Ropianka and Menilite formations and garnet occurring in crystalline rocks of the Bohemian Massif, as well as in detrital garnet delivered from the massif (e.g., Biernacka, 2012; Salata, 2013a, b and references therein) the metamorphic bodies may have similar lithology to those of the Bohemian Massif.

The diversity of euhedral tourmaline and zircon varieties suggests petrographic variability of crystalline source rocks. Brown tourmaline, typical of the schorl-dravite series, is not highly diagnostic since it may crystallise in igneous as well as metamorphic rocks. However, euhedral blue and pink varieties (although very scarce), suggesting elbaitic tourmaline composition, imply the presence of granites and pegmatites in the source area. The occurrence of igneous rocks is additionally indicated by the presence of elongated euhedral zircon, which is characteristic of rapidly cooled, porphyritic, shallow, sub-volcanic bodies of granite and gabbro, while euhedral short prismatic zircon crystals suggest, in turn, provenance from deeply situated, slowly cooled igneous intrusions (e.g., Corfu et al., 2003). The fact that sharp euhedral zircon and blue and pink euhedral tourmaline are a minor component in the heavy mineral populations studied may indicate that igneous bodies in the source re- gion were not large compared to the contribution from sedimentary or metasedimentary rocks.

To verify the hypothesis based on heavy mineral analyses the data obtained should be compared with the types of pebbles occurring in the formations studied. Rock fragments occurring in sandstones of the Ropianka Formation in the area of investigation are dominated by sedimentary rocks among which Jurassic limestones of the Štramberk-type prevail but quartz sandstones and coal clasts are also present (Wdowiarz, 1949). The group of crystalline rocks is represented by igneous and metamorphic fragments comprising up to 32 and $9 \%$, respectively (see Bromowicz, 1974). Igneous rocks are mainly granites while metamorphic rocks are represented by gneisses (Wdowiarz, 1949), metaquartzites and phyllites (Bromowicz, 1974, 1986 and references therein). According to Bromowicz $(1974,1986)$, judging by the frequency of pebbles, the contribution of crystalline rocks in the source area was smaller than that of sedimentary rocks. Such an inference may be also drawn from heavy mineral studies presented in this paper. In the region south-east of the area studied (near Bircza), Ropianka Formation sandstones, beside the kinds of pebbles noted above, contain also porphyritic andesite and dacite clasts (Nowak, 1963)

The Kliva Sandstone of the Menilite Formation, in contrast to the Ropianka Formation, does not contain such numerous and diverse clasts of exotic rocks, being dominated by sand. Among the pebbles mostly sedimentary rocks, coal fragments and coal-bearing shales have been described (Kotlarczyk and Śliwowa, 1963; Ślączka and Unrug, 1966; Kotlarczyk, 1976). Some information about crystalline pebbles come from the Widaczów area (Wdowiarz, 1949; D. Salata, A. Uchman, K. Dudek, pers. comm., 2013) and from the middle part of the Menilite Formation at Borek Nowy (Kotlarczyk, 1985), which implies that crystalline rocks may have been exposed not only during the Ropianka Formation sedimentation but also during the Menilite Formation sedimentation. However, specific lithological varieties and frequencies of crystalline rock pebbles in the Widaczów area remain currently unspecified.

The heavy mineral correlation trends juxtaposed with the small contribution of pebbles in the Menilite Formation and their larger contribution in the Ropianka Formation may reflect evolution of the source area. The area may have evolved from an initially elevated, rapidly eroded landscape (an immature passive margin), during sedimentation of the Campanian-Maastrichtian part of the Ropianka Formation (Upper Cretaceous-Paleocene), to a more subdued (mature passive margin) landscape, slowly eroded during accumulation of the Kliva and Boryslav sandstone types of the Menilite Formation (Oligocene) (Fig. 12). This inference may explain the delivery of a large part of the garnet and staurolite directly from their source rocks and thus the negative correlation trend of these minerals with the ZTR value in the part of the Ropianka Formation studied. During sedimentation of the Menilite Formation, a mature margin of the basin foreland developed as topographically less diverse areas with low relief, which favoured longer storage periods prior to deposition in the basin. In consequence, palimpsest sediments could develop, which could be redeposited later to deeper parts of the basin, resulting in the positive correlation of kyanite and staurolite with the ZTR value. The longer storage period may also explain the lack of apatite in the Menilite Formation. This model of local foreland evolution based on heavy mineral analyses is in agreement with the views by Kotlarczyk and Śliwowa (1963) and Kotlarczyk (1976), who suggested sandy beaches and coastal dunes at the margin of the Skole Basin during sedimentation of the Kliva Sandstone. 


\section{CONCLUSIONS}

Heavy mineral assemblages of the Ropianka and Menilite formations display comparable compositions in terms of mineral species and their varieties, which suggests provenance of minerals from lithologically similar rocks during sedimentation of both formations.

Heavy mineral assemblages display different frequencies of some mineral species between the formations. The Campanian-Maastrichtian part studied of the Ropianka Formation reveals higher amounts of zircon, garnet and apatite and traces of hornblende, while the Menilite Formation has a relatively higher content of staurolite and kyanite and contains andalusite, but lacks apatite and amphibole.

Negative correlation trends of the ZTR and garnet and staurolite content in both formations suggest that part of the garnet and staurolite population represent first-cycle delivery. Additionally, better correlation of ZTR and garnet content for the Ropianka Formation, compared to the Menilite Formation, suggests that direct delivery of first-cycle garnet was greater during the Ropianka Formation sedimentation. Positive correlation trends between the ZTR value and staurolite and kyanite content in the Menilite Formation suggest that these minerals could origin, to large degree, from sedimentary rocks or palimpsest sediments. Zircon and tourmaline varieties and their frequencies are very similar in both formations, suggesting that diversity of their host rocks in the source area did not change significantly in time.
All these conclusions may reflect differences in first-cycle/re-cycled minerals ratio in clastic input during sedimentation of the formations studied. The data suggest that first-cycle material and direct delivery were greater during the Ropianka Formation sedimentation, while during deposition of the Menilite Formation the contribution of material delivered from erosion of sedimentary rocks or redeposition of palimpsest sediments was prominent.

Mineral frequencies and ratios in the intervals studied of the Ropianka and Menilite formations, when compared with literature data concerning exotic rock pebbles, reflect evolution of the source area from an initially elevated (immature passive margin) landscape, during sedimentation of the Ropianka Formation, to more subdued (mature passive margin) landscape during accumulation of the Menilite Formation.

Integrated conventional and high-resolution analyses applied to comparative study of depleted heavy mineral assemblages, enable to determination of the provenance of minerals in mixed first-cycle and re-cycled clastic material, which is a necessary basis for further research.

Acknowledgements. The manuscript benefited from suggestions and comments of J. Rajchel (AGH University of Science and Technology), J. Biernacka (University of Poznań) and an anonymous reviewer, to whom we are kindly grateful. The work was financially supported by the Jagiellonian University DS funds.

\section{REFERENCES}

Biernacka J. (2012) Detritus from Variscan lower crust in Rotliegend sandstones of the Intra-Sudetic Basin, SW Poland, revealed by detrital high-pyrope garnet. Annales Societatis Geologorum Poloniae, 82: 127-138.

Bromowicz J. (1974) Facial variability and lithological character of Inoceramian Beds of the Skole Nappe between Rzeszów and Przemyśl (in Polish with English summary). Prace Geologiczne, 84: 1-81.

Bromowicz J. (1986) Petrographic differentiation of source areas of Ropianka Beds east of Dunajec River (Outer Carpathians, Poland) (in Polish with English summary). Annales Societatis Geologorum Poloniae, 56: 253-276.

Bukowy S. (1957) Remarks on the sedimentation of the Babica Clays (in Polish with English summary). Rocznik Polskiego Towarzystwa Geologicznego, 26: 147-155.

Corfu F., Hanchar J.M., Kinny P. (2003) Atlas of zircon textures. Reviews in Mineralogy and Geochemistry, 53: 468-500.

Eynatten H. von, DunkI I. (2012) Assessing the sediment factory: The role of single grain analysis. Earth-Science Reviews, 115: 97-120.

Friedrich O., Herrle J.O., Hemleben C. (2005) Climatic changes in the Late Campanian-Early Maastrichtian: micropaleontological and stable isotopic evidence from an epicontinental sea. Journal of Foraminiferal Research, 35: 228-247.

Galehouse J.S. (1971) Point counting. In: Procedures in Sedimentary Petrology (ed. R.E. Carver): 385-407. Wiley Interscience, New York.

Garzanti E., Andò S. (2007) Heavy mineral concentration in modern sands: implications for provenance interpretations. Developments in Sedimentology, 58: 517-545.

Gasiński M.A., Uchman A. (2009) Latest Maastrichtian foraminiferal assemblages from the Husów region (Skole Nappe, Outer Carpathians, Poland). Geologica Carpathica, 60: 283-294.
Gasiński M.A., Uchman A. (2011) The Cretaceous-Paleogene boundary in turbiditic deposits identified to the bed: a case study from the Skole Nappe (Outer Carpathians, southern Poland). Geologica Carpathica, 62: 333-343.

Gągała Ł., Vergés J., Saura E., Malata T., Ringenbach J.C., Werner P., Krzywiec P. (2012) Architecture and orogenic evolution of the north-eastern Outer Carpathians from cross-section balancing and forward modelling. Tectonophysics, 532-535: 223-241.

Geroch S., Krysowska-Iwaszkiewicz M., Michalik M., Prochazka K., Radomski A., Radwański Z., Unrug Z., Unrug R., Wieczorek J. (1979) Sedimentation of Węgierka Marls (Late Senonian, Polish Flysch Carpathians) (in Polish with English summary). Rocznik Polskiego Towarzystwa Geologicznego, 49: 105-133.

Hubert J.F. (1962) A zircon-tourmaline maturity index and the interdependence of the composition of heavy mineral assemblages with the gross composition and texture of sandstones. Journal of Sedimentary Petrology, 32: 440-450.

Jaskólski S. (1931) Contributions to the geology and petrography of the Carpathian Flysh in the vicinity of Rymanów (in Polish with English summary). Sprawozdania Państwowego Instytutu Geologicznego, 6: 697-741.

Jucha S. (1985) New features of structure of the Carpathian Foredeep and basement of the Carpathian Mts (in Polish with English summary). Przegląd Geologiczny, 33: 333-344.

Kamieński M., Peszat C., Rutkowski J. (1967) Petrographic variability of Carpathian sandstones and the problem of sandstone classification. Rocznik Polskiego Towarzystwa Geologicznego, 37: 499-508.

Kędzierski M., Leszczyński S. (2013) A paleoceanographic model for the Late Campanian-Early Maastrichtian sedimentation in the Polish Carpathian flysch basin based on nannofossils. Marine Micropalaeontology, 102: 34-50. 
Kiessling W., Flügel E., Golonka J. (2003) Patterns of Phanerozoic carbonate platform sedimentation. Lethaia, 36: 195-225.

Kotlarczyk J. (1966) Diatomite horizon of the Krosno Beds in the Skole Nappe, Polish Carpathians (in Polish with English summary). Studia Geologica Polonica, 19: 110-129.

Kotlarczyk J. (1976) Przyczynki do wyjaśnienia genezy piaskowców kliwskich w Karpatach Polskich. Sprawozdania z Posiedzeń Komisji Naukowej PAN, Kraków, 19: 185-187.

Kotlarczyk J. (1978) Stratigraphy of the Ropianka Formation or of Inoceramian beds in the Skole Unit of the Flysch Carpathians (in Polish with English summary). Prace Geologiczne PAN, Kraków, 108: 1-81.

Kotlarczyk J., ed. (1985) Geotraverse Kraków-Baranów-Rzeszów-Przemyśl-Ustrzyki Dolne-Komańcza-Dukla. Guide to excursion 4. Carpatho-Balkan Geological Association XIII Congress. Kraków, Poland 1985: 103-106. Geological Institute, Warszawa.

Kotlarczyk J. (1991) Modele basenów sedymentacyjnych jednostki skolskiej i zatoki rzeszowskiej. In: Paleontologia a Batymetria (ed. J. Kotlarczyk): 11-21. Materiały XIV Konferencji Paleontologów w Karpatach Rzeszowskich, Kamionka k. Rzeszowa.

Kotlarczyk J., Leśniak T. (1990) Lower part of the Menilite Formation and related Futoma Diatomite Member in the Skole Unit of the Polish Carpathians (in Polish with English summary). Wydawnictwo Akademii Górniczo-Hutniczej, Kraków.

Kotlarczyk J., Śliwowa M. (1963) On knowledge of the productive Carboniferous formations in the substratum of the eastern part of the Polish Carpathians (in Polish with English summary). Przegląd Geologiczny, 11: 268-272.

Kotlarczyk J., Uchman A. (2012) Integrated ichnological and ichthyological analysis of oxygenation changes in the Menilite Formation during Oligocene, Skole and Subsilesian nappes, Polish Carpathians. Palaeogeography Palaeoclimatology Palaeoecology, 331-332: 104-118.

Kotlarczyk J., Jerzmańska A., Świdnicka E., Wiszniowska T. (2006) A framework of ichthyofaunal ecostratigraphy of the Oligocene-Early Miocene strata of the Polish Outer Carpathian basin. Annales Societatis Geologorum Poloniae, 76: 1-111.

Ksiażkiewicz M., ed. (1962) Geological Atlas of Poland. Fascicle 13 - Cretaceous and Early Tertiary in the Polish External Carpathians. Instytut Geologiczny, Warszawa.

Lihou J.C., Mange-Rajetzky M.A. (1996) Provenance of the Sardona Flysch, eastern Swiss Alps: example of high-resolution heavy mineral analysis applied to an ultrastable assemblage. Sedimentary Geology, 105: 141-157.

Mange-Rajetzky M.A. (1995) Subdivision and correlation of monotonous sandstone sequences using high resolution heavy mineral analysis, a case study: the Triassic of the Central Graben. Geological Society Special Publications, 89: 23-30.

Mange M.A., Wright, D.T., eds. (2007a) Heavy Minerals in Use. Developments in Sedimentology, 58.

Mange M.A., Wright D.T. (2007b) High-resolution heavy mineral analysis (HRHMA): a brief summary. Developments in Sedimentology, 58: 433-436.

McManus D. (1975) Modern versus relict sediment on the continental shelf. GSA Bulletin, 86: 1154-1160.

Melinte M.C. (2005) Oligocene palaeoenvironmental changes in the Romanian Carpathians, revealed by calcareous nannofossils. Studia Geologica Polonica, 124: 341-352.

Morton A.C., Hallsworth C.R. (1999) Processes controlling the composition of heavy mineral assemblages in sandstones. Sedimentary Geology, 124: 3-29.

Morton A.C., Hallsworth C.R (2007) Stability of detrital heavy minerals during burial diagenesis. Developments in Sedimentology, 58: $215-245$

Nie J., Horton B.K., Joel E., Saylor J.E., Mora A., Mange M., Garzione C.N., Basu A., Moreno C.J., Caballero V., Parra M. (2012) Integrated provenance analysis of a convergent retroarc foreland system: $\mathrm{U}-\mathrm{Pb}$ ages, heavy minerals, $\mathrm{Nd}$ isotopes, and sandstone compositions of the Middle Magdalena Valley basin, northern Andes, Colombia. Earth-Science Reviews, 110 $111-126$.

Nowak W. (1963) Preliminary results of study on exotics from the Inoceramian Beds of the Skole series, of several sites in the Przemyśl and the Bircza Carpathians (in Polish with English summary). Kwartalnik Geologiczny, 7 (3): 421-430.

Powers M.C. (1953) A new roundness scale for sedimentary particles. Journal of Sedimentary Petrology, 23: 117-119.

Rajchel J. (1990) Lithostratigraphy of the Upper Palaeocene and Eocene sediments from the Skole Unit (in Polish with English summary). Zeszyty Naukowe AGH, Geologia, 48: 1-112.

Rajchel J., Myszkowska J. (1998) Exotic clasts of organodetritic algal limestones from lithosomes of the Babica Clay, Skole Unit (Outer Flysch Carpathians, Poland). Annales Societatis Geologorum Poloniae, 68: 225-235.

Salata D., Uchman A. (2012) Heavy minerals from the Oligocene sandstones of the Menilite Formation of the Skole Nappe, SE Poland: a tool for provenance specification. Geological Quarterly, 56 (4): 803-820.

Salata D. (2013a) Source rocks for heavy minerals in lower part of Menilite Formation of Skole Nappe (Polish Flysch Carpathians), based on study of detrital garnet and tourmaline. Annales Societatis Geologorum Poloniae, 83: 1-17.

Salata D. (2013b) Heavy minerals as detritus provenance indicators for the Jurassic pre-Callovian palaeokarst infill from the Czatkowice Quarry (Kraków-Wieluń Upland, Poland). Geological Quarterly, 57 (3): 537-550.

Salata D. (2013c) Garnet provenance in mixed first-cycle and poly-cycle heavy-mineral assemblages of the Ropianka and Menilite formations (Skole Nappe, Polish Flysch Carpathians): constraints from chemical composition and grain morphology. Annales Societatis Geologorum Poloniae, 83: 161-177.

Skulich J. (1986) Badania magmowych skał egzotycznych we wschodnich Karpatach fliszowych. Kwartalnik Geologiczny, 30 (1): 135-136

Soták J. (2010) Paleoenvironmental changes across the Eocene-Oligocene boundary: insights from the Central-Carpathian Paleogene Basin. Geologica Carpathica, 61: 393-418.

Szczurowska J. (1970) Minerały ciężkie w otworze wiertniczym Przysietnica IG-1. Kwartalnik Geologiczny, 14 (4): 915-916.

Szczurowska J. (1971) Wstępne badania minerałów ciężkich serii menilitowo-krośnieńskiej w odwiercie Jasień IG-1. Kwartalnik Geologiczny, 15 (3): 732.

Szczurowska J. (1973) Minerały ciężkie końcowego odcinka wiercenia Jasień IG 1 w Bieszczadach (cz. II). Kwartalnik Geologiczny, 17: 643-644.

Ślączka A., Unrug R. (1966) Sedimentary structures and petrology of some sandstone members of the Menilite Beds, Carpathians (in Polish with English summary). Rocznik Polskiego Towarzystwa Geologicznego, 36: 155-184.

Tokarski J. (1947) Ciężkie minerały jako wskaźniki stratygraficzne serii fliszowych. Nafta, 3 (9): 261-264.

Turner G., Morton A.C. (2007) The effects of burial diagenesis on detrital heavy mineral grain surface textures. Developments in Sedimentology, 58: 393-412.

Wdowiarz S. (1949) Structure géologique des Carpates marginales au sud-est de Rzeszów (in Polish with French summary). Biuletyn Państwowego Instytutu Geologicznego, 11: 1-51.

Wdowiarz S., Wieser T., Szczurowska J., Morgiel J., Szotowa W. (1974) Geological structure of the Skole Unit and its basement in the column of the Cisowa IG 1 borehole (in Polish with English summary). Biuletyn Instytutu Geologicznego, 273: 1-95.

Zachos J.C., Pagani M., Sloan L., Thomas E., Billups K. (2001) Trends, rhythms, and aberrations in global climate $65 \mathrm{Ma}$ to present. Science, 292: 686-693.

Żgiet J. (1963) Wstępna charakterystyka sedymentologiczna piaskowców kliwskich. Kwartalnik Geologiczny, 7 (4): 715-716.

Żytko K. (1975) Profil otworu wiertniczego Brzegi Dolne IG 1. Kwartalnik Geologiczny, 19 (4): 958-959. 